\title{
RESENHAS
}

\section{A melancolia dos historiadores}

\section{Ronaldo Vainfas}

Maria Lúcia Pallares Burke. As muitas faces da história. São Paulo: Unesp, 2000. 348 p.

É muito bem-vinda a publicação desta coletânea de entrevistas organizada por Maria Lúcia Garcia Pallares-Burke, reunindo, sob o título As muitas faces da história, depoimentos de nove scholars, - oito historiadores e um antropólogo de significativa contribuição, para dizer o mínimo, nos rumos seguidos pela historiografia dos últimos 30 anos. A quase totalidade deles, à exceção de Asa Briggs e Daniel Roche, é bem conhecida do público brasileiro especializado, pois tiveram livros importantes traduzidos, desde os anos 1980. É o caso de Cario Ginzburg, Peter Burke, Keith Thomas, Robert Darnton, Natalie Davis, Quentin Skinner e Jack Goody. Trata-se de excelente elenco de autores, os quais, seja pelos temas de investigação, seja pelas inovaçóes teórico-metodológicas que propuse- ram, irrigaram a pesquisa historiográfica contemporânea, chegando mesmo, em certos casos, a ultrapassar os muros da academia. Um dos casos mais expressivos talvez seja o de Natalie Davis, a única mullher selecionada para este team, cujo The Return of Martin Guerre (1983) foi traduzido para o alemáo, espanhol, português, francês, holandês, italiano, sueco, russo, e até para o japonês.

O livro de Pallares-Burke, tão logo publicado, já despertou a atenção dos especialistas, merecendo resenhas críticas de historiadores de peso em nosso meio. Evaldo Cabral de Mello publicou, no Caderno Mais (Folha de S. Paulo), uma bela análise do livro sob o título de "Historiadores no confessionário"; e Laura de Mello e Souza publicou, no Jornal de Resenhas do mesmo diário, artigo intitulado "A história em movimento". Impossível não dialogar com os eminentes colegas na análise que tentarei fazer 
do livro em foco - eles que, não obstante reparos pontuais, receberam a obra com grande entusiasmo. E, realmente, o livro é impecável, sob vários pontos de vista.

A introdução da organizadora explicita com nitidez a proposta da obra, bastante original, de trazer à luz os bastidores da produção historiográfica de autores de ponta, descortinando para o leitor as motivaçóes pessoais, as matrizes intelectuais e mesmo um pouco da história de vida que, de vários modos, encontra-se presente no trabalho de cada um. As entrevistas compóem, assim, um painel que se aproxima dos Ensaios de Ego-história publicados há uns 15 anos na França, incluindo eminentes historiadores da Nouvelle Histoire. Cada entrevista é precedida de concisa apresentação por parte da organizadora, na qual se informa sobre o autor entrevistado, sua obra e biografia, deixando o leitor perfeitamente à vontade para apreciar a entrevista. As chaves da entrevista são igualmente nítidas e pertinentes. Procuram relacionar aspectos biográficos com produção intelectual; verticalizam aspectos da produçáo de cada entrevistado; particularizam trajetórias específicas, quer acadêmicas, quer gerais, relaciona- das à política maior; provocam reflexóes de ordem teórica de grande importância quanto às relaçóes entre a história, de um lado, e a antropologia, a literatura, o marxismo, a política e outros tópicos. É assim possível avaliar, longe das simplificaçóes e estereótipos, inúmeros percursos e opçóes da chamada Nova História nas últimas décadas.

Mas é mesmo da Nova História que o livro trata, exceto por Asa Briggs, estudioso da cultura material e Skinner, mais dedicado à política e às instituiçôes, de modo que tem razáo Evaldo Cabral de Mello ao discutir a adequação do título As muitas faces da História. A história em causa, se for o caso de classificá-la, é sobretudo a chamada história antropológica, uma história que sem necessariamente negar processos gerais e totalidades amplas, debruça-se antes sobre enredos específicos, por vezes microscópicos, incluindo-se em vários casos na chamada microhistória. De modo que o leitor se depara, principalmente, com algumas — e só algumas — faces da Nova História, não havendo, entre os entrevistados, nenhum de seus críticos frontais ou de autores preferencialmente dedicados ao estudo das grandes estruturas. É como diz 
Evaldo, em sua análise, ao ressaltar que ali somente estấo reunidos autores que migraram "do porão ao sótão” na pesquisa historiográfica.

Laura de Melo e Souza também observou, com razão, que predominam autores da vertente anglo-saxã deste campo historiográfico - o que náo deixa de causar certo espanto, tendo sido a França o cenário privilegiado das mentalidades, em contraste com a Social History de língua inglesa, sabidamente marcada por forte empiricismo. Um autor como Serge Gruzinsky, por exemplo, - lembrado aliás por Laura historiador que, além de francês e muito inovador teoricamente, debruçou-se sobre a história colonial ibero-americana, seria muito bemvindo neste elenco predominantemente composto por estudiosos de temas europeus. Por outro lado, a quase "ausência" dos franceses em livro no fundo dedicado à Nova História é compensado pela forte presença de "francólogos" expressivos, se me for permitada a expressão, a exemplo de Burke, Darnton e Natalie Davis.

Os reparos de Evaldo e Laura, quefaço meus, não diminuem, porém, a qualidade da obra que, como disse, é cuidadosa na concepção e póe em cena inúmeros debates que animaram a polêmica historiográfica dos últimos anos. Evaldo Cabral de Mello observou, com olhar cirúrgico, um certo desapontamento dos autores entrevistados, alguma frustração por não terem estudado ou orientado teses, por exemplo, de história política ou diplomática. Como os políticos que experimentam a "melancolia do poder", os autores entrevistados parecem por vezes sentir uma certa "melancolia do conhecimento", permitindose dizer, em graus variáveis, que o marxismo, afinal, faz alguma falta e não está de todo morto; apontando os riscos que o demasiado apego à escala microscópica acarreta ao trabalho do historiador; "confessando”, em vários casos, o caráter aleatório das escolhas temáticas que os celebrizaram, como no caso extremo de KeithThomas, que admite ter estudado a feitiçaria por acaso, além de se dizer muito crédulo e influenciável, sempre prestes a esposar as idéias do último livro que venha a ler.

Esta "melancolia do conhecimento", que Evaldo apontou como um dos pontos instigantes do livro, poderá ser um "prato cheio" para os críticos ferrenhos da Nova História, sempre prontos a destroçá-la pelo 
apego a temas irrelevantes e minúsculos, pelo descritério metodológico, pelo desengajamento político, pela invenção de modismos, pelo "antropologismo" pulverizador, pelas interpretaçóes delirantes e, last but not least, pela rejeição da luta de classes.

A bem da verdade, nota-se mesmo um certo ar blasé em várias consideraçóes de alguns dos autores entrevistados. O melhor exemplo talvez seja o de Keith Thomas, que se compraz em dizer que nunca lera um artigo sequer dos Annales em sua formação universitária e de que Braudel, embora o tenha impacta-do, era, quando publicado, livro "indigerível" que "não pegou na sua época", a exemplo dos livros de Febvre e Bloch. Só se pode entender semelhante opiniáo partindo ela, como no caso, de autor inglês desinteressado de outras histórias além da britânica (e de fato as historiografias européias, ao contrário do que se imagina, dialogam muito pouco entre si). Mas é decepcionante ver um historiador do porte de Thomas sublinhar com tanta ênfase o improviso que caracterizou suas escolhas temáticas, seja no clássico $A$ religiáo e o declinio da magia, seja em $O$ Homem e o mundo natural.
Por outro lado, encontra-se em algumas entrevistas, aqui e ali, um certo gosto pelo paradoxo com forte sabor provocativo, coisa que autores deste porte, e já um tanto "melancólicos", como diria Evaldo, se permitem cultivar, por vezes exagerando pontos de vista externados em suas pesquisas, outras vezes levados pela atmosfera de confessionário que entrevistas desse tipo não raro ensejam. É o que vemos, por exemplo, numa das respostas de Goody a propósito do mito da "singularidade do Ocidente", quando afirma que a "Revolução Industrial nada mais fez do que copiar, numa produção em grande escala, a pioneira indústria asiática" - tipo da interpretação arrojada, em escala macro-histórica, que não resiste, porém, a qualquer evidência. É o que vemos numa das opinióes de Darnton - autor consagradíssimo - que, insistindo, com razão, no dever que tem o historiador de sempre conferir os fatos narrados, diz que, para tanto, todos "deveriam trabalhar algum tempo em algum jornal cobrindo estupros, assassinatos e assalto à mão armada”. Seria mesmo necessário tal estágio para o historiador zelar pelo rigor factual de suas pesquisas? 
Mas este elenco de entrevistas, se por essas e outras podem municiar os críticos acérrimos da chamada Nova História, oferecem, por outro lado, elementos preciosos para desfazer certos estereótipos de críticas por vezes simplificadoras ou "ideológicas".

Antes de tudo, o caráter antropológico desta história que muitos adversários da Nova História consideram uma espécie de pecado original da historiografia recente. Pois bem, a leitura atenta das entrevistas com esses grandes autores sugere relação pouco sistemática de quase todos eles com a Antropologia - melhor dizendo, com as antropologias - , quer em termos de formação intelectual, quer em termos de adoção sistemática de conceitos operativos. À exceção, por razões óbvias, do único antropólogo incluído no livro - e que por sinal se empenha em destacar seu projeto de historicizar a cultura a maioria dos entrevistados admite manter relação apenas pontual com alguns textos antropológicos de tendências e épocas diversas. Não é o caso de Peter Burke, por exemplo, que enumera os antropólogos que julga importantes e diz o porquê das escolhas. Não é também o caso de Ginzburg, mais parcimonioso nas citações, porém explícito sobre a importância de Lévi-Strauss no seu História Noturna. Keith Thomas é igualmente convincente quando se refere à influencia de Evans-Pritchard no seu The religion and the decline of magics. As várias menções a Cliford Geertz também são dignas de nota e muito já se escreveu sobre a poderosa influência de seu trabalho na chamada micro-história. Mas, na maior parte dos casos, a salutar aproximação com a Antropologia é, como afirmou Natalie Davis, movida por "razóes instrumentais", o que traduzo como: um refinamento da perspectiva $\mathrm{mi}$ croanalítica; uma atenção com as invariantes da sociedade, sem prejuízo de sua dinâmica; um cuidado especial com a descrição de detalhes ritualísticos e simbólicos - mas não, sob nenhum ponto de vista, a adoção de modelos antropológicos de interpretação. Quando muito, a adoção de certos conceitos, como o da descrição densa de Geertz, porém totalmente refundidos pela perspectiva diacrôníca da pesquisa histórica.

Outro ponto, que decorre do viés antropológico adotado por esses historiadores, diz respeito à microhistória. Trata-se de assunto inevi- 
tável, justamente provocado pela organizadora do livro, seja porque alguns deles realmente protagonizaram este gênero - Ginzburg, Natalie Davis —, seja porque, na visão dos críticos da Nova História, ela não raro aparece como sinônimo de micro-história, entendida como estudo de minudências irrelevantes, fantasmas, periferias do que é realmente essencial.

Pois o que se encontra no depoimento desses historiadores é, pelo contrário, uma consciência bastante nítida dos perigos de uma micro-história levada às últimas conseqüências, isto é, descontextualizada e exclusivamente narrativa e um tanto novelesca de casos isolados. Todos os entrevistados apregoam, em uníssono, a necessidade de se articular o global e o particular, o caso minúsculo e a sociedade inclusiva - ainda que tais conexóes sejam muitas vezes, em razão do recorte dos objetos, mais implícitas do que sistemáticas. Daniel Roche, historiador francês, talvez seja dos poucos a admitir, com tranqüilidade, não ser "um fato lamentável não se ter uma explicação global" para os fenômenos históricos. E nisso toca, embora despretensiosamente, num ponto essencial e sério da micro-história, coisa muito bem acentuada pelo seu conterrâneo Jacques Revel em outro livro, a saber: o que diferencia - mas não hierarquiza a macro e a micro-história é a escala de observação e não o esforço ou renúncia de explicaçóes. De minha parte, lastimo um pouco que os entrevistados não tenham aprofundado este ponto, insistindo apenas na necessária, porém dificílima, articulação entre microanálise e generalização.

Um terceiro estereótipo que as entrevistas reunidas no livro póem em xeque é a propalada idéia de que a Nova História não faz diferença, dado o seu apego à narrativa, entre história e ficção. Por mais que Asa Briggs enfatize a importância da "evidência literária”; que o próprio Ginzburg admita que, por vezes, a "distinção entre ficção e não-ficção se torne muito pouco clara"; que Natalie Davis, et pour cause, insista em que "a escrita da história exige uma habilidade que é imaginativa" - nenhum dos autores em causa renuncia à prova dos fatos. Fatos verdadeiros - porque, em alguma medida os há, como há os fatos deliberadamente mentirosos -; e fatos ao menos verossímeis, que são a maioria. A factualidade 
comprovável é, pois, em qualquer escala, dimensão importantíssima do trabalho historiográfico, e sobretudo por isso sua escrita não haverá de ser ficcional. Um quarto e último ponto - que longe está de esgotar a riqueza de questóes postas pela coletânea - diz respeito à relaçóes ente esses autores e o marxismo. E nisso me afasto um pouco da conclusão de Laura que, na sua resenha do mesmo livro, salienta que para eles seria importante "revistar o marxismo antes de alardear a sua morte". Natalie Davís, que já foi simpatizante do socialismo, afirma que nunca se convertera ao marxismo, na verdade. Keith Thomas, perguntado sobre se o marxismo de Cristopher Hill o influenciara, afirmou que, antes disso, fora realmente seduzido pela personalidade de Hill, sendo que ele, Thomas, quando muito, não passara, quando jovem, de um "marxista vulgar". Peter Burke não evita afirmar que nunca fora marxista e prefere mesmo o ecletismo teórico. Robert Darnton não se acanha em dizer que náo relê Marx freqüentemente "nem procura em sua obra chave para resolver algum problema”. Cario Ginzburg, um dos que mais valoriza a luta social em sua obra e vota no PC italiano, não hesita em dizer que "nunca se declarou marxista", seja por ignorar o conjunto da obra de Marx, seja pelo seu pouco comprometimento com a esquerda. $\mathrm{O}$ mais enfático nesse ponto é, sem dúvida, Daniel Roche, para quem o ecletismo é preferível "a continuar dizendo, como se fazia, que a economia dita tudo...”. A julgar por esses depoimentos, vários desses historiadores nem estiveram no poráo, antes de se instalarem no sótão.

De modo que, na verdade, o marxismo náo parece gozar de grande prestígio entre esses autores. Não o marxismo in totum - e nisso Laura tem razão - , pois todos eles admitem estar ali uma chave para entender a importância dos conflitos de classe na história. Mas o marxismo realmente rejeitado por esses autores e pela Nova História, em geral, é aquele que - vulgar ou refinado - apregoa o determinismo econômico, mesmo que "em última instância”, e vê na luta de classes "o motor da história".

E nem por rejeitarem esses pressupostos, com maior ou menor contrangímento, tais autores podem ser vistos como absolutamente "desengajados”. Em geral são eleitores da esquerda ou de propostas à es- 
querda, ainda que titulados de Lord ou Sir, defendem, como militantes, inúmeras causas de minorias, como a das mulheres ou de grupos étnicos oprimidos; Jacques Goody chegou a se engajar em lutas anticolonialistas na África...

A história é mesmo mais rica do que a luta de classes ou o determinismo econômico - e não se poderia compreender o passado e o presente a partir, exclusivamente, desses dogmas. É isto, também, o que nos mostra esse livro de entrevistas e a Nova História, em geral, com perdáo pelo uso do rótulo impreciso. Mostra-nos que nem mesmo o capitalismo entronizou de vez o homo oeconomicus; que a lógica da diferença é tão importante quanto a lógica do conflito, sem cair em relacivismos radicais; que a observação microscópica é tão capaz de explicar a história como as interpretaçóes de conjunto, respeitada a diferença de escalas; que o conflito social possui, além da luta de classes, múltiplas dimensóes — étnicas, religiosas - e talvez essas últimas tenham produzido e produzam as tragédias mais dramáticas da história.

A biografia e a historiografia desses autores mostra que superaram intelectualmente o século XIX e atravessaram as tragédias, dilemas e utopias do XX. Não se escusam de enfrentar os dilemas do século XXI, embora, com enorme lucidez, muita melancolia e alguma prudência, evitem dar lições arrumadas. 